\title{
SALEZJANIE W ODPOWIEDZI NA POTRZEBY WYCHOWANIA WE WSPÓŁCZESNEJ EUROPIE
}

\begin{abstract}
Streszczenie: W artykule przedstawiono współczesny kontekst wychowawczy Europy z jego wielorakimi wyzwaniami, zagrożeniami i szansami. Autor skupia się przede wszystkim na wyzwaniach globalizacyjnych, w tym na wzrastającym w Europie poziomie wielokulturowości i wieloreligijności. Jego zdaniem jest to nowa sytuacja, inna od tej z przeszłości, która stanowi duże wyzwanie dla instytucji wychowawczych prowadzonych przez salezjanów. Wychowanie współcześnie nie może być pielęgnowaniem przeszłości, lecz zmusza do odważnego poszukiwania aplikacji charyzmatu Jana Bosko w warunkach zgodnych z mentalnością współczesnych Europejczyków, a w szczególności młodzieży.
\end{abstract}

Słowa kluczowe: charyzmat, Jan Bosko, globalizacja, tożsamość, wielokulturowość, wychowanie

Żyjemy w czasach ciekawych, choć niekoniecznie łatwych, powodujących rewolucyjne zmiany globalne prawie we wszystkich obszarach życia człowieka. Niektórzy nazywają tę sytuację kompresją czasu i przestrzeni (Harvey 1996) oraz podkreślają, że trudno sobie do końca wyobrazić, jakie będą tego skutki (Degl'Innocenti i in. 2001, s. 54). Jedną z cech globalizacji jest rosnąca niepewność (Morawski 2005, s. 32), która towarzyszy współczesnemu człowiekowi także na polu wychowania. Przełożony generalny salezjanów Ángel Fernández Artime opisuje obecną młodzież kultury zachodniej jako osoby bez marzeń i często niedostrzegające na horyzoncie realizacji swoich celów życiowych (Expòsito 2015, s. 114). Jednym z wielkich wyzwań współczesności staje się wychowanie młodego pokolenia. Stawia ono przed salezjanami europejskimi pytanie o aktualność ich misji wychowawczej.

Spoczywający u podstaw zachodzących zmian proces globalizacji można różnie rozumieć. Jedni utożsamiają go z osiągnięciami ludzkiego geniuszu, inni wprost przeciwnie - ze złem (Bonaglia, Goldstein 2003, s. 9). Zdaniem niemieckiego socjologa Ulricha Becka we współczesnym świecie wszelkie działania dokonują się „pod coraz bardziej piekącym słońcem globalizacji” (Beck 1997, s. 13). Anthony Giddens doprecyzowuje, że doświadczana obecnie bezsilność wychowawcza nie jest znakiem porażki, lecz nieadekwatności i niedostosowania dotychczasowych instytucji i struktur edukacyjnych. Jeżeli chce się wykorzystać pozytywnie siłę procesu 
globalizacji, konieczne staje się zreformowanie istniejących struktur i stworzenie nowych. Według Anthony'ego Giddensa globalizacja to nie „wypadek przy pracy”, lecz trwała zmiana sposobu współczesnego życia (Giddens 200o, s. 32). W związku z tym należy stwierdzić, że działalność wychowawcza salezjanów znajduje się z konieczności w okresie transformacji. Ta konieczność wynika przede wszystkim z nowych wyzwań, jakie - przywołując słowa Benedykta XVI - są pochodną konsumpcyjnego stylu życia, hedonizmu, laicyzacji czy relatywizmu (Benedetto XVI 2007). Ponadto „salezjańska Europa” musi zmagać się z nierównowagą między liczbą salezjanów a liczbą prowadzonych przez nich dzieł, co wiąże się z procesem gwałtownego starzenia się zgromadzenia i brakiem nowych powołań. Szansę na rozwiązanie tego problemu daje współpraca z osobami świeckimi, którą zalecano na Kapitule Generalnej XXV. To z kolei wymaga zmiany mentalności i reorganizacji struktur salezjańskich (Chávez 2008). Przez wielu ruchy te są zwiastunami pozytywnych, choć niełatwych przekształceń.

\section{Charyzmat salezjański w Europie}

W roku 2010, wizytując niemieckich salezjanów, podziwiałem ośrodki edukacyjno-wychowawcze usytuowane na terenie byłej Niemieckiej Republiki Demokratycznej (NRD). Po zburzeniu muru berlińskiego salezjanie kupili we wschodniej części Berlina ruiny budynków, które - po ich wyremontowaniu - służą setkom młodych Europejczyków. Prawie całą pracę wychowawczą prowadzą w nich osoby świeckie, a salezjańska wspólnota im w tym pomaga. Gdyby nie obecność świeckich współpracowników, realizacja charyzmatu księdza Bosko byłaby niemożliwa.

Innym przykładem przemian zachodzących w sposobie urzeczywistniania charyzmatu salezjańskiego w Europie jest Polska. Nasz kraj charakteryzuje się głębokim przywiązaniem do tradycji i szeroką gamą propozycji wychowawczych. W polskich szkołach salezjańskich młodzież gromadzi się codziennie na tzw. słówku na dzień dobry, które ma za zadanie zachęcić do przeżywania dnia w duchu wiary. Poza tym młodzi ludzie mogą korzystać z kaplicy szkolnej, w której kapłani służą w sakramencie pokuty, a w czasie uroczystości szkolnych wielu młodych ludzi przystępuje do komunii świętej. Są to obrazy współczesnej Europy salezjańskiej, których nie powinniśmy się wstydzić.

Powyższe przykłady dowodzą, jak różny jest nasz kontynent, jak szybko i głęboko zmienia się jego obraz. Salezjanie starają się dostosowywać do nowej sytuacji. Nie ulega wątpliwości, że charyzmat księdza Bosko wymaga ponownego odczytania, co wiąże się często z porzuceniem dotychczasowych miejsc, form i metod pracy oraz wykoncypowaniem nowych propozycji. Przykładem tego może być działalność salezjanów w Wielkiej Brytanii. Zamykają oni niektóre inicjatywy wychowawcze po to, żeby zainicjować nowe, bardziej odpowiadające zmienionym potrzebom. Jak nigdy przedtem trzeba dzisiaj mieć oczy szeroko otwarte, żeby dostrzec, gdzie znajduje się młodzież. 


\section{Ksiądz Bosko wczoraj i dziś}

W poszukiwaniu odpowiedzi na współczesne wyzwania wychowawcze decydujące jest odniesienie do księdza Bosko i jego biografii. Co zrobiłby, gdyby dzisiaj stanął na ulicy któregoś z europejskich miast? Z pewnością to samo, co w połowie XIX wieku w Turynie, gdzie $\mathrm{z}$ odwagą wychodził do młodzieży zagubionej i wałęsającej się po ulicach. Jego postawa może być inspiracją do odnowy charyzmatu wychowawczego w ośrodkach salezjańskich rozsianych po całej Europie. Warto przy tym pamiętać, że ksiądz Bosko nie szedł do młodzieży elitarnej, lecz na ulice targanego problemami społecznymi Turynu, gdzie wyzysk młodego człowieka był na porządku dziennym. Święty wychowawca jako jeden z pierwszych postulował otoczenie opieką prawną młodocianych robotników, żądając dla nich zawierania formalnych umów o pracę, co dzisiaj przypominają związki zawodowe. Nie zapomnijmy, że ksiądz Bosko szedł także do więzień, przez co wywoływał zmieszanie na twarzach hierarchów kościelnych. Te niekonwencjonalne działania zaskarbiły mu podziw nie tylko chrześcijan, lecz również wyznawców innych religii. Myśl wychowawcza księdza Bosko jest przedmiotem badań naukowych na wielu uniwersytetach w świecie.

\section{Nowy kontekst wychowawczy w Europie}

Globalizacja powinna być odczytywana nie tylko jako problem, lecz także jako szansa wychowawcza. Wychowanie należy realizować nie tylko w parafiach i tradycyjnych oratoriach, ale przede wszystkim na ulicach miast, w szkołach publicznych, w klubach młodzieżowych, dyskotekach, parkach itp. Nie ma co ukrywać, że brak działań w tym zakresie demaskuje kompleksy wychowawcze salezjanów. Co zatem robić? Chcę przywołać sytuację z włoskiego miasta Perugia, w którym miejscowy ordynariusz, kardynał Gualtiero Bassetti, postawił na pracę z młodzieżą w stylu księdza Bosko. Na przestrzeni kilku lat powstało przy parafiach diecezjalnych kilkadziesiąt oratoriów. Wiele z nich nosi imię księdza Bosko, mimo że nie są prowadzone przez salezjanów. Czy nie powinniśmy w tym dopatrywać się wyzwania rzuconego salezjanom? Wydaje się, że tak, choć jest to równocześnie odkrycie „starego” geniuszu wychowawczego księdza Bosko i jego aktualności w dzisiejszych czasach.

Współczesną Europę charakteryzuje różnorodność i skomplikowana struktura problemów wychowawczych. Nie ulega wątpliwości, że wymusza to na salezjanach przemyślenie strategii działania, by były adekwatne do warunków, w których przyszło im realizować charyzmat księdza Bosko. Środowisko wychowawcze stawia wychowawców salezjańskich przed nowymi wyzwaniami. Pierwszym z nich jest zmieniająca się mentalność Europejczyków. Wyraźnie widać, jak globalizacja przeorała mentalność ludzi, zwłaszcza młodych (Kaczor 2004, s. 21). Współczesna Europa potrzebuje, jak nigdy dotąd, pozytywnego myślenia (Rozmus 1997, s. 19-21). 
System uprzedzający księdza Bosko opiera się na pozytywnym budowaniu przyszłości wychowanka i to powinno wyraźniej wybrzmiewać w przesłaniu kierowanym do współczesnych młodych Europejczyków.

Drugim wyzwaniem jest uwzględnienie sytuacji demograficznej. Europa, czy szerzej cywilizacja zachodnia, znajduje się na progu zapaści demograficznej. Jeśli nic się nie zmieni, to grozi jej upadek. W branych pod uwagę próbach zaradzenia temu problemowi mówi się również o wzroście liczby imigrantów, co z kolei rodzi nowe kwestie wychowawcze. Ten stan rzeczy jest wielkim wyzwaniem dla salezjanów w Europie.

Trzecim jest kryzys powołań, objawiający się malejącą liczbą osób obierających życie konsekrowane. W tej sytuacji ciężar działań wychowawczych przesuwa się coraz bardziej z salezjanów na ich współpracowników. Jest to specyficzny problem, który dotyka już prawie wszystkie kraje Europy, w tym również Polskę, mimo że nie wszyscy chcą go dostrzec. Przełożony generalny Pascual Chávez w relacji o stanie zgromadzenia przed Kapitułą Generalną XXVI pisał następująco: „Wszyscy jesteśmy świadomi trudnej chwili, jaką przeżywa chrześcijaństwo, a w nim życie konsekrowane [...]. Skutek jest taki, bez zbytniego uogólniania, że większość zgromadzeń doświadcza zmniejszającej się liczby [własnego - T.R.] personelu” (Chávez 2008, s. 288). Potrzebne są nowe strategie scalające działalność wychowawczą salezjanów i osób świeckich.

Czwartym wyzwaniem wychowawczym są przekształcenia w sferze wartości (Bera 2008, s. 28). Współczesna młodzież jest pierwszym pokoleniem w Europie, które dobrowolnie i masowo odchodzi od wiary swoich ojców (Matteo 2011, s. 24-26). Dokonujące się zmiany należy jednak interpretować szerzej niż tylko w odniesieniu do religijności. Istnieje pilna potrzeba rewizji poglądów na temat wartości i etyki, które kształtują nasze pojęcie świata globalnego (Opdebeeck 2009, s. 61). Współczesny filozof niemiecki Otfried Höffe uważa, że u podstaw współczesnego kryzysu gospodarczego leży kryzys wartości. Żeby przetrwać, Europa potrzebuje nowych (Höffe b.r.).

Nie brakuje takich, którzy w globalizacji widzą zmierzch wartości chrześcijańskich, tradycyjnie związanych z kulturą Europy. Innego zdania jest francuski historyk kultury, religii i mentalności nowożytnej Jean Delumeau, który twierdzi, że globalizacja jest właściwie wielką szansą dla chrześcijaństwa. Jego zdaniem Kościół katolicki jest również globalny, czyli powszechny. Realizuje swoją uniwersalną misję wobec wszystkich narodów i na każdej płaszczyźnie ludzkiego życia (Delumeau 2009). Papież Benedykt XVI w encyklice Caritas in veritate przytacza słowa swojego poprzednika Jana Pawła II: „globalizacja a priori nie jest ani dobra, ani zła. Będzie tym, co uczynią z niej sami ludzie” (Jan Paweł II 2001, s. 80o).

Piątym i ostatnim wyzwaniem jest sama kultura europejska. Zauważa się wyraźne rozejście się kultury i wiary. Na dramatyczne konsekwencje tego rozłamu wskazywał już papież Paweł VI i jego diagnoza nie straciła nic ze swej aktualności (Evangelii nuntiandi, nr 20). 
Te i inne jeszcze wyzwania zmuszają do poszukiwania nowej tożsamości wychowawczej salezjanów. Jeżeli chcą oni zachować charyzmat księdza Bosko, nie mogą trwać biernie w zastanych formach i strukturach działania wychowawczego, lecz muszą budować mosty łączące ich ze współczesnym pokoleniem ludzi młodych.

\section{W poszukiwaniu nowej tożsamości}

Na podstawie powyższej analizy sytuacji wychowawczej i wyzwań stojących przed salezjanami da się wyodrębnić kilka postulatów. Pierwszym z nich jest konieczność „rewaloryzacji” rzeczywistości, czyli ponownej oceny sytuacji, w której realizowany jest charyzmat księdza Bosko. Skoro każdy współczesny wychowawca staje przed imperatywem zmiany własnych paradygmatów, to tym bardziej dotyczy to salezjanów. Wysiłek ten wchodzi w zakres Nowej Ewangelizacji, polegającej nie tylko na odnowie programów czy projektów, lecz na prawdziwym nawróceniu myślenia (Attard 2014, s. 36).

Drugim postulatem jest troska o podnoszenie jakości oddziaływania wychowawczego. Współcześni chrześcijanie mają coraz większą świadomość, że słabością wyznawanej przez nich wiary jest powierzchowność i niska na ogół jakość praktyk religijnych, sprowadzających się często do zrutynizowanych działań. W wielu częściach Europy ta sprawa jest poważnym problemem wychowawczym. Szansę na jego rozwiązanie dostarcza Nowa Ewangelizacja Europy, jednak będzie ona skuteczna tylko dzięki autentycznemu świadectwu wiary i życia, co jest związane z sięgnięciem do chrześcijańskich korzeni Europy.

Trzeci postulat to konieczność dialogu ze wszystkim, co określa przymiotnik „nowy”. Odkrywamy go nie tylko tam, gdzie mówi się o potrzebie Nowej Ewangelizacji, nowej mentalności, nowych znakach czasu (Ruini 2005, s. 3), lecz również nowym wychowaniu. Na nie właśnie zwrócił uwagę przełożony generalny salezjanów, pisząc: „Dzisiaj może istnieć kształcenie, które nie bierze pod uwage problemów życia. Jest to powszechnie obecne w narzekaniach młodzieży. Może istnieć przygotowanie zawodowe pozbawione wymiaru etycznego czy kulturalnego. Może istnieć wychowanie ludzkie zamknięte w wymiarze doczesnym, które ucieka od pytań o sens ludzkiej egzystencji. Dlatego mówienie o «nowym wychowaniu» jest prawdziwą koniecznością, wypływającą ze zmienionej sytuacji społecznej i kulturowej. Oczywiście, nowe wychowanie potrzebuje «nowych wychowawców»" (Chávez 2008, s. 307).

W zacytowanym powyżej fragmencie znalazł się kolejny postulat, na który należy zwrócić uwagę. Jest nim konieczność doskonalenia wychowawców przez systematyczną formację nie tylko intelektualną, lecz również duchową. Współcześnie zmienia się diametralnie rola nauczyciela i wychowawcy. Przestaje się liczyć jego przekaz werbalny, a zyskuje na znaczeniu towarzysząca obecność w rozwoju młodego człowieka. Wymaga ona specyficznych kompetencji i umiejętności (Garito 2009). W tym kontekście trudno nie przypomnieć sobie salezjańskiej asystencji. 
Jej istotę oddaje znakomicie stwierdzenie: „gdy uczą się nauczyciele, uczą się uczniowie" (Hirsh, Killion 2009).

Innym polem wymagającym podjęcia właściwych działań jest międzyosobowa komunikacja. W świecie zdominowanym przez wszechobecną technikę palącą potrzebą wychowania staje się komunikacja, która - jak się powszechnie uważa - jest współcześnie bezładna, zaburzona, narażona na dwuznaczności przez nadmierny hałas, mnogość informacji, brak zgodności między nadawcą i odbiorcą. Dobrze oddaje to obraz młodych odciętych od otoczenia przez słuchawki na uszach. W takich warunkach wspólne dochodzenie do porozumienia nie jest łatwe, a nawet bywa niemożliwe. W systemie prewencyjnym Jana Bosko nie sposób wyobrazić sobie wychowania bez osobowej komunikacji między wychowankiem i wychowawcą. Tego dialogu nie są w stanie zastąpić żadne, nawet najnowocześniejsze środki techniki.

Poszukiwanie odpowiedzi na współczesne wyzwania powinno uwzględnić także prorocki charakter posłannictwa salezjańskiego. To właśnie on określa nowe miejsce charyzmatu salezjańskiego we współczesnej kulturze. W grudniu 2004 roku ówczesny kardynał Joseph Ratzinger, uczestnicząc w Rzymie w spotkaniu prowincjałów salezjańskich, stwierdził, że przyszłość europejskich salezjanów zamyka się w proroctwie wychowania (Chávez 2008, s. 306). Prorok ukazuje bowiem nowy sposób patrzenia na rzeczywistość, jest znakiem nadziei, mobilizuje, otwiera nowe perspektywy i nie koncentruje uwagi na samym sobie. Prorok nie zamartwia się o egoistyczne zachowanie własnego status quo. Właśnie takimi prorokami powinni stawać się współcześni wychowawcy salezjańscy.

Ostatnim postulatem jest większe uwzględnienie działania opatrzności bożej, która - jak uważał ksiądz Bosko - zawsze stawia wychowawców wobec aktualnych wyzwań, tak jest i dzisiaj. „Oto dlaczego Ksiądz Bosko osiągnął świętość osobistą, będąc wychowawcą. Oto dlaczego zdołał wychować świętą młodzież, jak Dominik Savio. Oto dlaczego istnieje związek między świętością i wychowaniem. Oto dlaczego dla wychowawcy fakt wychowania jest doświadczeniem duchowym. To jest nasza przyszłość. To jest naszym proroctwem!” (Chávez 2008, s. 308).

\section{Podsumowanie}

Poszukiwanie odpowiedzi na współczesne wyzwania wychowawcze w Europie nie jest bynajmniej proste. Mimo to salezjanie z nadzieją i pedagogiczną kreatywnością stają wobec młodych, wzorując się na księdzu Bosko. W ten sposób chcą wnosić cenny wkład w budowanie społeczeństwa współczesnej Europy. Biorąc za wzór księdza Bosko, starają się zrozumieć swoje czasy i tak zmodyfikować działania wychowawcze, aby dostosować je do nowych sytuacji i oczekiwań.

Jest oczywiste, że zmiany cywilizacyjne same w sobie nie stanowią problemu. Problem wynika ze sposobu, w jaki się do nich podchodzi, i to właśnie jest największym wyzwaniem dla charyzmatu salezjańskiego w Europie. Trzeba z energią i twórczym zapałem poszukiwać nowej tożsamości na miarę nowych czasów, 
w których przyszło nam żyć. Inspiracji do takiej postawy dostarczają apostołowie zgromadzeni w Wieczerniku. Przestraszeni i zrezygnowani nie wiedzą, co mają robić po śmierci Chrystusa. Momentem przełomowym staje się zesłanie Ducha Świętego. Ten Duch napełnia ich nieznaną dotąd mocą i odwagą, która daje początek całej historii Kościoła. Czegoś podobnego potrzebuje dzisiaj Europa i Kościół: spojrzenia pełnego wiary i nadziei, realizmu i odwagi, ale także ufności w sukces wychowawczy.

\section{Bibliografia}

Attard F. (2014). La Pastorale Giovanile Salesiana. Quadro di Riferimento. Roma: Dicasterio per la Pastorale Giovanile Salesiana.

Beck U. (1997). Was ist die Globalisierung? Irrtümer des Globalismus - Antworten auf Globalisierung. Frankfurt am Main: Suhrkampf Verlag.

Benedetto XVI ai Vescovi slovacchi in Visita „ad limina”, dostępny na: https:// www.google.it/\#q=Benedetto+XVI+ai+Vescovi+slovacchi+in+Visita+\%E2\%80 $\% 9 \mathrm{Ead}+$ limina\%E2\%80\%9D+ (otwarty 15.06.2007).

Bera R. (2008). Aksjologiczny sens pracy a poczucie jakości życia młodych emigrantów polskich. Lublin: Wydawnictwo UMCS.

Bonaglia F., Goldstein A. (red.). (2003). Globalizzazione e sviluppo. Due concetti inconciliabili? Quattro luoghi comuni da sfatare. Bologna: Il Mulino.

Chávez P.V. (2008). Relazione del Rettor Maggiore Pascual Chávez Villanueva. CG26. Roma: Editrice SDB.

Chávez P.V. (2014a). Relazione del Rettor Maggiore Pascual Chávez Villanueva. CG27. Roma: Editrice SDB.

Chávez P.V. (2014b). Testimoni della radicalità evangelica. Lavoro e temperanza. Documenti Capitolari CG27. Roma: Editrice SDB.

Degl'Innocenti E. i in. (red). (2001). Scuola lavoro. Progetto orientamento. Torino: Paravia Bruno Mondadori Editori.

Delumeau J. (2009). Globalizacja jest szansą dla chrześcijaństwa, dostępny na: http://tischner.pl/aktualnosc/96/1/jean-delumeau-globalizacja-jest-szansa-dla-chrzescijanstwa (otwarty 23.10.2009).

Expòsito A. (2015). Don Bosco oggi. Intervista a Don Ángel Fernández Artime decimo successore di Don Bosco. Roma: Libreria Editrice Vaticana.

Garito M.A. (2009). Globalizzazione e Innovazione, le Nuove Opportunità, di Istruzione e Formazione, dostępny na: http://www.garito.it/allegati/8/ Saggi/orglobalizz_innovaz.pdf (otwarte 19.06.2009).

Giddens A. (200o). Il mondo che cambia. Come la globalizzazione ridisegna la nostra vita. Bologna: Società Editrice Il Mulino.

Harvey D. (1996). Justice, nature and the geography of difference. Oxford: Blackwell. Hirsh S., Killion J. (2009). When educators learn, students learn. Eight principles of professional learning, dostępny na: http://digitalliteracy.us/educators_learn.pdf. 
Höffe O. (b.r.). Obecny kryzys odmieni nasz system wartości?, dostępny na: http://wiadomosci.onet.pl/2179943,11,obecny-kryzys-odmieni-nasz-system-wartosci,item. html (otwarte 21.06.2015).

Jan Paweł II (2001). Przemówienie do Papieskiej Akademii Nauk Społecznych. „Insegnamenti”, nr 1.

Kaczor S. (2004). Miejsce edukacji dorosłych w przemianach mentalności Polaków. „Edukacja Ustawiczna Dorosłych”, nr 1.

Kasiske F. (2005). Supply Chain Management im Kontext der europäischen Verkehrspolitik. Aachen: Schaker.

Matteo A. (2010). La prima generazione incredula. Roma: Rubbettino.

Morawski W. (2005). Globalizacja i praca. Kontekstowa analiza świata pracy. W: Borkowska S. (red). Przyszłość pracy w XXI wieku. Warszawa: IPISS.

Opdebeeck H. (2009). Can one prevent globalization leading to ethical decay? Globalization, health and bioethics. W: Mordini E. i in. (red.). Ethics and health in the global village. Bioethics, globalization and human rights. Roma: CIC.

Paolo VI (1975). Evangelii nuntiandi, dostępny na: http://w2.vatican.va/content/ paul-vi/it/apost_exhortations/documents/hf_p-vi_exh_19751208_evangelii-nuntiandi.html.

Ratzinger J. (2004). Europa. I suoi fondamenti oggi e domani. Milano: Edizioni San Paolo.

Rozmus T. (1997). Szkolnictwo zawodowe potrzebuje optymistów. „Dyrektor Szkoły”, nr 1.

Ruini C. (2005). Nuovi segni dei tempi. Le sorti della fede nell'età dei mutamenti. Milano: Mondadori.

Semeraro C. (2010). I padri dell'Europa. Alle radici dell'Unione Europea. Città del Vaticano: Libreria Editrice Vaticana.

\title{
SALESIANS AND THE REQUIREMENTS OF CONTEMPORARY EUROPEAN EDUCATION
}

\begin{abstract}
In this article author presents the contemporary educational context of Europe, with its multiple challenges, threats, and opportunities. It focuses mainly on many different challenges of globalization, marked especially by growing European context of multiculturalism and multireligiosity. The new educational situation, different from that of the past, constitutes a major challenge for educational institutions also for the Salesians and requires a new approach. The education of today's youth cannot be limited only to mourn the past, but also to courageous search for a new identity of the charism of Don Bosco, adapted to the mentality of contemporary Europeans, especially young people.
\end{abstract}

Keywords: charism, John Bosco, globalization, identity, multiculturalism, multireligiosity 
Tadeusz Rozmus - salezjanin, doktor pedagogiki, członek Rady Generalnej Towarzystwa Salezjańskiego, odpowiada za region Europy Środkowej i Północnej. Publikacje książkowe: Stuchać i naśladować (2003), Duch Święty i jego dary w naszym życiu (2006), Don Bosco alle catacombe (2011). Adres e-mail: tadeusz.rozmus@gmail.com. 